\title{
Human Resource Management, Services and Relationship Marketing: The Potential for Cross-Fertilisation
}

\begin{abstract}
This conceptual paper notes the re-casting of marketing from a focus on products and transactions to a focus on services and relationships - strongly implying that people are core to the delivery of promises. In so doing, it highlights that the recruitment, training, development, retention, rewarding and management of people are therefore central in achieving strategic marketing objectives, building on extant research which confirms that a satisfied workforce contributes to the creation of happy customers. This highlights that marketing has a great deal to learn from HR, and perhaps the means to achieve key strategic marketing objectives already exist within the domain of HR theory and practice? Structurally, the paper summarizes the evolution of marketing from the transactional to the relational and focuses on selected areas in which value could be obtained for marketers in drawing on the existing HR literature and concepts before considering what the future relationship between marketing and HR could, and should be.
\end{abstract}

Keywords: marketing, relationship marketing, human resource management, management, management structure 


\section{Introduction - the wide and narrow context}

Our rational is that - as will shortly be seen - the language, centricity and strategy of marketing is now expressed using terminology that will be very familiar to those comfortable with discourses in Organisational and HR literature and practice, especially within the context of understanding and improving effectiveness and efficiency in managerial/hierarchical structures, processes and control mechanisms. Indeed, the main theme of this paper is the potential for concepts to be 'borrowed' from HR domains for the purpose of providing structure, clarity and enrichment to marketing theory and practice. Our main claim is that integration between the processes of marketing and HRM is helpful at the tactical level and critical at the strategic level in order to achieve and maintain collective, organisational success. Such integration is a silver-bullet, a transformation that will augment performance and therefore an issue of direct and significant relevance to both fields. Indeed, it is an issue that has been discussed previously in the literature (Ferrin et al, 2007; Strong and Harris, 2004; Vlaar et al, 2007; Crosby and Stephens, 1987).

Before we expand on this thesis, it is necessary to consider the narrow context of evolution in marketing that has brought it to a position where ideas from HR or Organisational literature are of increasing relevance and significance to marketers. That step requires a few comments on the wider context of business research, education, training and managerial and academic specialisation.

Let us take that wider context first. In the hard sciences, it has long been understood that the borderlines between disciplines and specialisms are often areas with the potential for rapid advance. Considerations of the border territories between chemistry and biology - the science of biochemistry - has led to some of the most significant scientific discoveries of the last 100 years, including the discovery and modelling of DNA. Biologists recognise the 
importance of understanding the language and concepts of chemistry and vice-versa. Is the same true for different groups of academics in a business school? Is it easy or common for one group of specialists to discuss and communicate their ideas with groups outside their own specialism? We suggest not. We hope this paper will attract and encourage cross-disciplinary attention and dialogue as the connections between marketing and HR need to be built amongst scholars and practitioners.

That interdisciplinary research is desirable is not a new argument. Nor is the significance of the overlap between organisation management/HR and marketing a topic that has never been addressed (Chimhanzi, 2002; Cobb et al, 1998; Currie and Procter, 2001; Schneider et al, 1998; Wang et al, 2011). But, if we accept the premise that the fundamental nature, structure and assumptions of marketing have changed almost beyond recognition then the connection, interface and relationship between marketing and the rest of the set of organisational processes requires re-examination.

\section{Marketing - from products to services - from transactions to relationships}

At this point we switch to the narrow context of the quite radical changes in marketing theory and assumptions in the last 30 years that have taken it a long way away from its origins in microeconomics, North America and the 1950s (Harker and Egan, 2006). The in/famous 4P framework emerged from econometric modelling of oligopolistic competition as derived lists of key variables from 'profit-maximising' equations (Chamberlain, 1933; Waterschoot and Van Den Bulte, 1992; McGarry, 1950; McKitterick, 1957; Alderson, 1957) were turned by the 'functionalist school' of marketing (McGarry, 1950; Borden, 1954) into a simple, comprehendible subset of four variables (McCarthy, 1960) from twelve identified as 
being strongly correlated with profitability - product, price, branding, distribution, personal selling, advertising, promotions, packaging, display, servicing, physical handling, fact finding and analysis. Interestingly, in the context of our discussion, a number of the variables which failed to make the 'cut' relate to human involvement and intervention. Perhaps early marketing theorists, in striving for the simplicity of just four variables set aside the importance of people within the process? This would only begin to be remedied with the emergence of services marketing in the 1980s.

This "highly effective impact machine" (Grönroos, 1996: 16) worked well within the time and the place in which it was developed - the North American consumer goods markets of the post-war era - and US inspired management education spread what is now labelled as Transactional Marketing until it became the dominant marketing paradigm (Kent, 1986). Gradually, it became apparent that most marketing situations and markets had characteristics significantly different from those of North American consumer goods markets through one or both of geography or business context/sector (Elg and Johansson, 1996; Waterschoot and Van Den Bulte, 1992). Rather than start again by challenging the conceptual basis of Transactional Marketing, the quickest and most convenient 'solution' to the problem was to paper over the cracks. The standard method of overcoming deficiencies in the $4 \mathrm{P}$ "tablet of faith" (Grönroos, 1994) was to expand on the same approach - abstracting the market/ing relationship into a list of decision making variables (Brodie et al, 1997; Grönroos, 1994) as was done with services marketing (Booms and Bitner, 1982), where people, physical evidence and process brought the total to 7Ps. Specialists in people or process management who read that list of additions are likely to raise eyebrows at this. These additions were an implicit admission that marketing mix management/Transactional Marketing was failing to satisfy modern marketing conditions - as reflected in the changing nature of these markets and consumers. Mass markets had begun to fragment. Customers had become more 
sophisticated and demanding, requiring products and services tailored to their specific needs (Bennett, 1996; Christopher et al, 1991). What the Transactional Marketing paradigm had become in practice was not a customer-orientated approach to business but a productorientated philosophy (Grönroos, 1994; Gummesson, 1997) that additionally failed to account for the great and growing significance of services on their own and additionally as key components of branded product offerings - a context within which it has long been argued that there are objectives over and above attracting customers. It is also required to keep and maintain the customer, and often helpful and profitable to develop a long-term relationship with them (Bitner et al, 1994; Cravens and Piercy, 1994; Grönroos, 1991; Gummesson, 1987). The implications of this are that organisations must be more long-term focussed and that this means more effectively managing customer relations and retention strategies in order to help secure long-term profitability and stability (Berry, 1995; Parasuraman et al, 1991; Grönroos, 1990).

It is because of this that Vargo and Lusch $(2004 a, 2006,2008,2009)$ have notoriously argued that a service rather than product-focused concept of marketing is a more natural and accurate reflection of the primacy of services in contemporary marketing practice and that therefore the 'dominant logic' of marketing should be service-orientated. There is a great volume of debate within the marketing community about whether relationships or services should be primary - e.g. is a service part of a relationship, or is a relationship perhaps part of a service (Gummesson and Grönroos, 2012)?

Regardless, both services marketing and RM make the case that the people responsible for service provision and/or customer-contact are of significance with respect to successful implementation of marketing strategy and therefore to the success of the organisation as a whole. 'People' is one third of the 'services marketing mix', bolted onto the 4Ps' framework in order to remedy some of its shortcomings. The actual abilities and talents of these people 
receives short shrift in marketing literature (Ballantyne, 1997; Judd, 1987). Crucially, Transactional Marketing takes little account of the role front line staff can play in creating, developing and maintaining relationships [or providing excellent customer service] over a long period of time. The people they meet are critical in the mind of the consumer when they are assessing the ability of the company to serve them well. People working for the organisation are who the customer trusts or does not trust, people in the organisation give good customer service and do the job properly or they do not. It is the people - not the abstract concept/entity/branding of the firm, who truly learn about the customers and whom the customers learn about the firm through, it is the people from whom the customer expects (and sometimes gives to) loyalty, trust and commitment (Giannakis and Harker, 2014). To many customers, the firm is its people (Gummesson, 1991).

\section{Take in Table 1 about here}

It can be argued therefore, that firm-customer relationships are key, especially in sectors where services and service provision are battle-winning differentiators. Organisations must therefore consider relationship management to be at the heart of tactical marketing processes and strategic corporate philosophy. Consideration must be given to what and who is at the other end of the relationship to the customer, as marketing success will be to a great extent the result of successful management of people. These people will include customers outside the business and front-line staff providing services within. In line with Vargo and Lusch's position, successful marketing strategy is thereby becoming increasingly focussed on developing and retaining competitive advantage through excellent services marketing which is in turn based on services provision which is of course an outcome of the abilities and 
performance of service providers and the quality and ability of service providers is a function of Human Resource Management and organisational management of individuals, teams and groups. This, in turn, has led to the re-emergence of internal marketing (Ferdous and Polonsky, 2014; Collins and Payne, 1991; Hales, 1994) as a strategy by which to build loyal relationships between customers and a firm's own employees. This, in turn, can be seen to arm people-managers with the tools normally associated with their consumer marketing colleagues as a means of supporting functions such as the recruitment and retention of employees (Kale, 2007). A further elaboration of this theme is through the notion of employee branding, building people directly into the marketing and brand offer of the organization. Building and supporting the brand through people, therefore, represents a confluence of marketing and HRM which is directly pertinent to our discussion here (Ind, 2001; Buckingham, 2008; Brannan, Parsons and Priola, 2011). Table 1 gives a list of selected readings for HR specialists so as to inform them on this history, evolution and realignment within marketing.

In short, successful marketing requires successful people management. We will return to these themes at a later stage in the development of this argument.

\section{The need for marketing to draw on HR and Organisational Theory and concepts}

Here then is the rationale of this paper in its simplest form. If marketing is now about people and relationships rather than products, it is in need of concepts and theory about people and relationships. Drawing on extant theory and research in Human Resource Management and Organisational Behaviour (see Bach and Sisson, 2000 for an overview and Chang and Huang, 2005 for a parallel narrative) may provide the basis for meeting this need. 
It is not possible to give a comprehensive schema, therefore our chosen exemplars of how the relative poverty of RM theory can be enriched will be deliberately limited to just three areas. Firstly a key concept based on the actors - the customers and staff co-producing marketing outcomes. Secondly concepts considered to form the building blocks of marketing relationships - commitment, trust and loyalty. Finally, the significant role of HR in Internal Marketing.

Firstly, the concept of the 'part-time marketer' [hence PTM] was introduced in Gummesson's seminal paper (1991), which built on previously existing services marketing theory, and noted other research showing the critical significance of the service production/delivery process in respect of customer opinion formation (Lehtinen, 1983). A PTM is a person associated with the company (at least in the mind of the customer) who has the ability to make an impression on the customer's judgement of the firm - regardless of the role in which the person is officially employed. Examples commonly given include technical and support staff, as well as front-line staff in more traditional customer-facing roles. Since 1991, this idea of the importance of PTMs has been developed by others (Berry, 1995; Bitner et al, 1994; Harker, 2004; Iocabucci and Ostrum, 1996).

Indeed, and as a precursor to our argument for the integration and alignment of HR/OB and RM theory, Gummesson stated that in the majority of the 'moments of truth' that occur between firm and customer, customer perception is governed much more by the interaction between customers and the staff members they engage with than by the usually marginal impact of the actions [and expenditure] of a distant and disconnected 'marketing department'. Rather, perception of the firm and the quality of the services they receive by the customer is primarily governed in services markets by the PTMs, "often they are the only marketers around" (Normann, 1983: 26). This, in turn, links to the established notion in HR of the boundary-spanning worker, a front line employee whose role straddles their responsibility to 
the firm and their commitment to meet customer needs and requirements (Aldrich and Herker, 1977; Singh et al, 1996; Onyemah et al, 2010; Bateson and Hoffman, 2011), an approach extended to responsibility for the management of boundaries with respect to the wider stakeholder community by Hult (2011). To the customer, the firm is not the brand - but its people (ironically, in the case of front-line staff, often those with the lowest status and remuneration within service organizations). If the significance and importance of PTM staff is accepted, then it follows that marketing is about managing the relationships between people - some of whom are customers, some of whom are staff.

What else can be taken from HR/OB literature in developing this idea? We would suggest a great many things. There is value for marketing theory in exploring - amongst other directions - HR thought on staff recruitment, retention, development, and on the formation and management of teams (see for example Breaugh, 2008). Those are all core HR topics - "It is true that when a firm's employees are happy, efficient, well trained and properly paid, its customers are more likely to be happy, too” (Wells and Spinks 1998). Cartwright and Holmes (2007) have taken a pragmatic look at how employee cynicism and engagement can be better managed - key to making sure that the company-node of the relationship is a healthy, appropriate and pro-active individual. The contribution of employees to objectives common with marketing, the profitability and competitiveness of the organization, is at the heart of the service profit chain (Heskett et al, 1997; Heskett, 2002; Yee, et al, 2011).

Human Resource Development - a developing concept in the literature - can be defined as "supporting and facilitating the learning of individuals, groups and organisations" (McGoldrick et al., 2002, pp. 396, Bates et al. 2001). US researchers typically note that the main purpose of HRD is to enhance learning, human potential and high performance in workrelated systems. There are researchers who claim that Human Resource Development defies 
definition and boundaries. "It's difficult to put into a box" (Blake, 1995, pp. 22), a view affirmed by both Lee (2001) and McGoldrick et al (2002). Vince (2012, p.130) addresses the span and scope of HRD in arguing that it "should be conceptualised as an approach that supports the impact that people can have on organising. The focus of HRD is on action, on developing the capacity to act, on generating credibility through action and on influencing and working with others in situations loaded with emotion and politics". Additionally, a useful definition of Strategic Human Resources Development (SHRD) contends that: "The strategic management of training, development and of management/professional education interventions, so as to achieve the objectives of the organisation while at the same time ensuring the full utilization of the knowledge in detail and skills of individual employees. SHRD, is concerned with the management of employee learning for the long term keeping in mind the explicit corporate and business strategies" (Garavan, 1991, pp. 17).

Our second issue is based on a key early work in the development of RM, the 'commitment-trust' theory of Morgan and Hunt (1994). They argued that commitment and trust are amongst the crucial factors that distinguish productive, effective relational exchanges from those that are inefficient and ineffective. Furthermore, commitment and trust between partners in a marketing network leads directly to 'co-operative behaviours' in three ways. Firstly, they predispose the partners towards actively preserving relational 'investments'. Secondly they help to prevent partners from adopting short-term, opportunistic behaviours. Thirdly, they help to support the view of high-risk actions as being prudent in the longer term (Hunt, 1997). Morgan and Hunt constructed what they call the KMV (Key Mediating Variable) model to show the central importance of commitment and trust in marketing relationships. Empirical support for this KMV model was provided through quantitative research in the American automobile tyre retail industry (Morgan and Hunt, 1994) and by a further study in UK health care (Kalatatis and Miller, 1996). This model is 
repeated below, decontextualized from the complex mathematics for the sake of brevity and sanity. It seems likely that readers with more than a little knowledge of HR/OB will take in the set of keywords and automatically make connections to HR/OB concepts and ideas. We draw attention in particular to the work of Vlaar et al (2007), who looked at the concept of trust across functions and groups, whilst Ferrin et al (2007) developed a theoretical framework from the base of previously existing interpersonal and intergroup literature on trust and co-operation.

\section{Take in Figure 1 Here}

If 'commitment' and 'trust' are accepted as key conceptualisations in the definition of Relationship Marketing, they must in turn be examined. Two definitions of commitment within the context of network interaction are offered by Morgan and Hunt. "An exchange partner believing that an ongoing relationship with another is so important as to warrant maximum efforts at maintaining it; that is, the committed party believes the relationship is worth working on to ensure that it endures indefinitely" (Morgan and Hunt, 1994). "Commitment to the relationship is defined as an enduring desire to maintain a valued relationship" (Moorman et al, 1992: cf Morgan and Hunt, 1994) Both of these definitions draw on social exchange theory, energetically developed within HR literature.

Trust is defined fourfold, "we conceptualise trust as existing when one party has confidence in an exchange partner's reliability and integrity" (Morgan and Hunt, 1994). "Trust is defined as a willingness to rely on an exchange partner in whom one has confidence" (Moorman et al, 1992: see Morgan and Hunt, 1994). "Trust is a generalised expectancy held by an individual that the word of another ...can be relied on" (Rotter, 1967: 
cited Morgan and Hunt, 1994). "The firm's belief that another company will perform actions that will result in positive outcomes for the firm as well as not take unexpected actions that result in negative outcomes" (Anderson and Narus, 1990). Trust is an expectation of behaviour by the exchange partner in keeping with promises made by that partner.

O’Malley and Tynan (1997) note that the definitions advanced by Morgan and Hunt are operational definitions, which are situationally specific. HR/OB has much it could contribute to the understanding of trust in marketing relationships - indeed, the work of Ferrin et al (2007) alone is much more rigorously constructed and richer and deeper than the combined contribution of marketing theorists to date.

A number of discussants, (Bratton and Gold ,1999; Beardwell and Holden, 1997; Guest, 1995, 1998; Sanders et al, 2008; Taylor et al, 2008; Tremblay et al, 2010), have identified that within HR practices, more employee commitment results in higher performance outputs for the organisation. Bratton and Gold (1999, pp. 357) suggest that "the new HRM model seeks to elicit high commitment from workers and thereby cultivate proactive behaviour with committed workers expending effort levels 'beyond contract' for the enterprise". These and other studies have identified that committed employee behaviour is at the heart of HRM and is in fact a "central feature that distinguishes HRM from traditional personnel management" (Guest, 1995, pp. 112).

Employee commitment has been described in HR and OB literature as:

Attitudinal commitment - that is loyalty and support - involvement for the firm, strength of identification with the organisation (Porter 1985). The classical notion of corporate loyalty suggests that individuals are recruited for a specific task for which they should show their gratitude by behaving in a loyal and committed manner (Kiechel, 1985). 
Normative commitment is defined as "the totality of internalized normative pressures to act in a way that meets organisational goals and interests and suggests that individuals exhibit behaviours solely because they believe this is the right and moral way in which to behave" (Wiener, 1982, pp. 421). Thus, a normative commitment is one of obligation.

Behavioural commitment, as outlined in the works of Staw and Salancik (1977), develops as a result of an individual's past actions that are ultimately binding. It occurs, "when an individual has identified himself with a particular behaviour" (Salancik, 1977, pp. 64), and adjusts his attitude to fit that behaviour. Walton (1985) considers that commitment is thought to result in better quality service-provision by the employees, hence lower turnover rates, higher levels of experience, a greater capacity for innovation and improvisation and a generally more flexible work force. However, Pfeffer (1998), Wood and Albanese (1995) and Meyer and Allen (1997) argue that employee commitment is a core variable. Whitener (2001:530) concludes her empirical analysis by noting that "These results indicate that employees' trust and commitment are stronger when they perceive that the organization is committed to and supportive of them". Guest (1998, pp. 42) further suggests "the concept of organisational commitment lies at the heart of any analysis of HRM. Indeed the whole rationale for introducing HRM policies is to increase levels of commitment so that other positive outcomes can ensue.”

The notion of employee commitment is a conceptual building block that only scratches the surface of the potential for integrating HR and OB into marketing. Building commitment is at the heart of the notion of internal marketing to which we have already alluded. For Varey and Lewis (1999: 938), internal marketing “represents the convergence of a number of previously separate management technologies, such as human resource development, employee relations, strategic management, quality management, corporate communications and macro-marketing". 
Our third selection was internal marketing under the new rubric. Rafiq and Ahmed (1993), in an early paper, explored the relationship between internal marketing and HRM as a route to understanding where one stops and the other commences. They reach the conclusion that there is a case to transfer or, maybe, outsource some traditional HRM functions to those responsible for marketing. Commitment, supported by an internal marketing approach, may, in turn, stimulate organizational or structural empowerment (as opposed to psychological empowerment which is a somewhat more complex concept). This focuses on organizational structure, policies, procedures, and roles of managers and leaders in granting power to employees (Dewettinck and Ameijde 2011; Seibert, Wang and Courtright, 2011). It aims to disseminate, decentralize and share power, as well as delegating authority, and allowing formal control and responsibility to all organizational levels (Seibert, Wang and Courtright, 2011; Maynard, Gilson and Mathieu, 2012), especially to employees in the lowest and most customer-proximate positions, thus enabling them to make decisions that will affect organizational outcomes, act on their own initiative, without the need to consult their supervisors .

\section{Human Resource Management and Marketing - the need for strategic integration and alignment}

This paper has begun to explore - using the existing literature - the requirement of better strategic alignment of RM and HRM as a means of successfully implementing relational strategies. That is - given the recasting of successful marketing in terms of services and relationships excellence, and the key role therefore played by service providers it is necessary to bring ideas from RM and HRM together. Here then is our main conclusion. Without 
successfully 'aligning' $\mathrm{HR}$ and marketing strategy and implementation, services and relational quality will be impaired and therefore potential for competitive advantage lost. In this lies the contribution to practice. Effective management is multi-dimensional, and HR and marketing are two of the key dimensions. The shift in strategy in marketing from sales/product orientation to a services/relationships orientation has implications for $\mathrm{HR}$ structure, strategy and process. Without adaptation in HR, 'true' RM strategy cannot be designed or applied. Implications and connections relate to themes such as the selection, retention, training and development of staff but also for their working conditions, their pay and for organizational attitudes towards work-life balance issues (Hughes and Bolton, 2002). In short, there is a compelling imperative that HR and marketing be aligned. Labovitz and Rosansky (1997, pp.5) define alignment "as both a noun and a verb - a state of being and a set of actions . . . alignment . . refers to the integration of key systems and processes and responses to changes in the external environment". Often the concept of alignment when used in business is referred to as strategic fit (Smaczny, 2001), strategic match (Mintzberg et al, 1998), or simply the interface between two things (van der Zee and De Jong, 1999).

Thus, a product of this collaborative/competitive association is consensus on the critical importance of people in the implementation of an effective RM strategy. This and surrounding issues have already been the focus of much study and reflection by HR scholars (e.g. Arthur and Boyles, 2007).

Take in Table 2 about here 
It was noted above that the authors of this paper hope it will be the beginnings of a new dialogue between HR and marketing specialists. The above Table 2 is presented as a short list of key readings in marketing. The consumption of some or all of these will enable external scholars to see many areas in which they could make important contributions to the development of marketing. The first group tells the story of the evolution of marketing from being product focussed to services/relationships focussed and the second selects works associated with key elements of marketing theory where the potential for development through application of HR theory seems great.

Taking the recipe for valid theoretical contributions from Whetton (1989) the what of this paper is the list of concepts, practices and processes selected from recent HR and OB literature as collectively and individually adding dimension and detail to relatively unshaped RM concepts. The how [are they related] comes from the overlap between evolutions in HR theory and practice and the current vector of research in marketing - our argument is that HR and marketing might be considered on adjacent and parallel paths to a common destination and that explanations and understanding of human actions, interactions, hierarchy, power, negotiation, training and so on will be of increasing relevance and significance to marketing management. That point links heavily with the why. If marketing scholars are arguing for the dominance of services/relationships in marketing - and therefore the primacy of people in effective marketing - then it seems impossible to avoid the conclusion that existing ideas in adjacent disciplines which have a deeper, wider and stronger and more direct connection to their theoretical underpinnings are of relevance.

It seems certain that drawing on ideas like these from outside the marketing domain is a means to more efficiently and effectively impelling the development of services and relationships orientated marketing strategies. Indeed, should we be surprised to see commonality of philosophy and vocabulary between the HR and marketing literatures? Both 
have multiple applications of words like loyalty, commitment, trust, long-term. This may be largely explained by a similarity in intent - flexibility, adaptability - and the acknowledgement that both marketing and HR writers desire that their disciplines form a corporate wide philosophy/culture as a set of processes. Perhaps it might be better to consider that Marketing and HR form important components of organisational culture together within the rubric of Organisational Behaviour as a whole?

If we accept the key role that front-line staff play in facilitating services and relationships with external groups - including customers - then it seems ridiculous to not also accept that the recruitment, training, development, retention, rewarding and management of these people in the process are also important, especially when research already exists demonstrating that a happy workforce helps to cause happy customers. If we argue that concepts like loyalty, commitment and trust are of critical importance in understanding successful long-term interactions between parties, then it seems nonsensical to ignore a vast literature-resource in which these concepts have been highly developed and considered over decades.

Therefore, and in summary, if a company is going to build and maintain strong relationships with its customers, it seems certain that a key means of doing this will be by improving management of people. A fundamental change in what is regarded as successful marketing requires equally fundamental re-examination of the impact and interfaces of marketing on other business processes. We argue that the reverse is also true - the HR community must consider the implications of their own evolutions in theory and practice in order that assumptions, processes and objectives can be made complimentary if not synergetic with those of marketing and other management specialities. 
We hope this paper makes a contribution to that issue and is a small part of the answer to the implied managerial question - 'I want to make my organisation more services and relationships orientated. How do I do that?' 


\section{Bibliography}

Alderson, W. (1957) Marketing Behaviour and Executive Action Irwin, Homewood, Illinois.

Anderson, J.C. and Narus, J.A. (1990) A Model of Distributor Firm and Manufacturer Firm Working Partnerships Journal of Marketing, 4, pp. 42-58.

Aldrich, H., and Herker, D. (1977), Boundary Spanning Roles and Organization Structure, Academy of Management Review, 2(2), pp. 217-230.

Arthur, J.B. and Boyles, T. (2007), Validating the human resource system structure: A levels-based strategic HRM approach Human Resource Management Review, 17(1), pp. 7792.

Bach, S. \& Sisson, K. (2000), Personnel management in perspective, In Bach, S. and Sisson, K. (Eds.). Personnel Management, A Comprehensive Guide to Theory and Practice, 3rd ed., Blackwell, Oxford, pp. 3-42.

Ballantyne, D. (1997), Internal networks for internal marketing, Journal of Marketing Management, 13, (5), pp. 343-366.

Bates, R., Hatcher, T., Holton, E. and Chalfonsky, N. (2001), Redefining human Resource development: an integration of the learning, performance and spirituality or work perspectives, Proceedings of the Annual AHRD Conference, February- March, Tulsa.

Bateson, J. \& Hoffman, K. (2011), Services Marketing, Mason, OH: South-Western Cengage Learning. 
Beardwell, I., \& Holden, L. (1997), HRM: A Contemporary Perspective. London: Pitman.

Bennett, R. (1996) Relationship Formation and Governance in Consumer Markets: Transactional Analysis Versus the Behaviourist Approach, Journal of Marketing Management, 12 pp. 417-436.

Berry, L. L. \& Parasuraman, A. (1991), Marketing Services: Competing through Quality, New York: The Free Press.

Berry, L. L. (1995), Relationship Marketing of services—growing interest, emerging Perspectives, Journal of the Academy of Marketing Science, 23(4), pp. 236-4.

Bitner, M.J., Booms, B.H., \& Mohr, L.A. (1994), Critical Service Encounters: The Employee's Viewpoint. Journal of Marketing, 58, pp. 95-106.

Blake, R.R. (1995), Memories of HRD, Training and Development, 49(3), pp. 22-9.

Booms, B. H., and Bitner, M. J. (1981), Marketing Strategies and Organisation Structures for Service Firms in J. Donnelly \& W. R. George (Ed). Marketing of Services. Chicago: American Marketing Association.

Borden, N.H. (1964) The Concept of the Marketing Mix, Journal of Advertising Research, 4 June, pp.2-7.

Brannan, M., Parsons, E. \& Priola, V. (2011), Introduction, in (eds) Brannan, M., Parsons, E. \& Priola, V., Branded lives. The production and consumption of meaning at work, Cheltenham: Edward Elgar.

Bratton, J. \& Gold, J. (1999), Human Resource Management, Hampshire: Macmillan. 
Brencic, M., Pfajfar, G., and Raškovic, M. (2012) "Managing in a time of crisis: marketing, HRM and innovation", Journal of Business \& Industrial Marketing, 27(6), 436 446

Breaugh, J. A. (2008) Employee recruitment: Current knowledge and important areas for future research Human Resource Management Review 18(3), pp. 103-118.

Brodie, R.J., Coviello, N.E., Brookes, R.W and Little, V. (1997), Towards a Paradigm Shift in Marketing? An Examination of Current Marketing Practices, Journal of Marketing Management, 13, pp. 383-406.

Buckingham, I. (2008), Brand engagement: How employees make or break brands, Basingstoke: Palgrave Macmillan.

Camps, J. and Luna-Arocas, R. (2012), A Matter of Learning: How Human Resources Affect Organizational Performance. British Journal of Management, 23, 1-21

Cartwright, S. and Holmes, N. (2007) The meaning of work: The challenge of regaining employee engagement and reducing cynicism, Human Resource Management Review 16(2), pp. 199-208.

Chamberlain, E.H. (1933) The Theory of Monopolistic Competition, Cambridge, Mass: Harvard University Press

Chang, W, J. A. and Huang, T. C. (2005) Relationship between strategic human resource management and firm performance - A contingency perspective, International Journal of Manpower Vol. 26 No. 5, pp. 434-449

Chimhanzi, J. (2002), The impact of marketing/HR interactions on marketing strategy implementation, European Journal of Marketing, 38(1/2), pp. 73-98. 
Christopher, M., Payne, A. \& Ballantyne, D. (2004), Relationship Marketing: Creating Stakeholder Value, Elsevier, Oxford.

Chang, W, J. A. and Huang, T. C. (2005) Relationship between strategic human resource management and firm performance - A contingency perspective, International Journal of Manpower, 26(5), pp. 434-449.

Cobb, J. C., Samuels, C. J. \& Sexton, M. W. (1998), Alignment and strategic change: a challenge for marketing and human resources. Leadership \& Organisation Development Journal, 19 (1), pp. 32-43.

Collins, B. and Payne, A. (1991) Internal Marketing: A new perspective for HRM, European Management Journal, 9(3), pp. 261-270.

Cravens, D. W. \& Piercy, N. F. (1994), Relationship Marketing and Collaborative Networks in Service Organisations, International Journal of Service Industry Management, 5 (5), pp. 39-54.

Crosby, L. A. and Stephens, N. (1987), Effects of Relationship Marketing on Satisfaction, Retention, and Prices in the Life Insurance Industry. Journal of Marketing Research, 24, pp. 404-411

Currie, G. and Procter, S. (2001), Exploring the relationship between HR and middle managers, Human Resource Management Journal, 11(1), pp. 53-69.

Day, G.S., Deighton, J., Narayandas, D., Gummesson, G., Hunt, S.D., Rust, R.T., Prahalad, C.K., and Shugan, S.M. (2004) Invited Commentaries on Vargo and Lusch Journal of Marketing, 68, January, pp.18-27. 
Dewettinck, K. and van Ameijde, M., (2011), Linking leadership empowerment behaviour to employee attitudes and behavioural intentions: Testing the mediating role of psychological empowerment, Personnel Review, 40(3), pp.284-305.

Elg, U. and Johansson, U. (1996) "Networking when national boundaries dissolve" European Journal of Marketing; 30(2), pp. 61-74.

Ferdous, A.S. and Polonsky, M. (2014) The impact of frontline employees' perceptions of internal marketing on employee outcomes Journal of Strategic Marketing, forthcoming

Ferrin, D, Bligh, M. \& Kohles, J. (2007) Can I Trust You to Trust Me? A Theory of Trust, Monitoring, and Cooperation in Interpersonal and Intergroup Relationships Group and Organization Management, 32(4), pp. 465-499.

Garavan, T. N. (1991), Strategic human resource development, Journal of European Industrial Training, 15(1), pp. 17-30.

Garavan, T, N., Heraty, N., \& Barnicle, B. (2000), Human resource development literature: current issues, priorities and dilemmas, Journal of European Industrial Training, 23(4/5), pp. 169-79.

Giannakis, D. and Harker, M.J. (2014) Strategic alignment between relationship marketing and human resource management in financial services organizations Journal of Strategic Marketing, Vol. 22, no. 5, pp. 396-419

Grönroos, C. (1990), Service Management and Marketing, Managing the Moments of Truth in Service Competition, Lexington, MA: Free Press/Lexington Books.

Grönroos, C. (1991), The marketing strategy continuum: towards a marketing concept for the 1990's management decision. Management Decision 29(1), pp. 7-13. 
Grönroos C. (1994), From marketing mix to relationship marketing, towards a paradigm shift in marketing, Management Decision, 32 (2), pp. 4-20

Grönroos, C. (1996) "Relationship marketing: strategic and tactical implications" Management Decision; 34(3), pp. 5-14

Guest, D. (1995), Human Resource Management, trade unions and industrial Relations in (ed) J. Storey, Human Resource Management: Still Marching on or Marching out? Human Resource Management: A Critical Test. London: Routledge

Guest, D. (1998), Beyond HRM: Commitment and the contract culture. In PP. Sparrow and M. Marchington (Eds.), Human resource management: the new agenda, London: Financial Times, Pitman Publishing.

Gummesson, E. (1987), The New marketing - Developing long term interactive relationships. Long Range Planning, 20 (4), pp. 10-20

Gummesson, E. (1991) Marketing Orientation Revisited: The Crucial Role of the PartTime Marketer, European Journal of Marketing; 25(2), pp.60-75

Gummesson, E. (1997) Relationship Marketing - The Emperor's New Clothes or a Paradigm Shift, Marketing and Research Today, Feb 1997, pp. 53-60.

Gummersson, E. and Grönroos, C. (2012), The emergence of the new service marketing: Nordic School perspectives, Journal of Service Management, 23(4), pp. 479-497.

Harker, M. J. (2004), Lenses and mirrors: the customer perspective on part-time Marketers, Marketing Intelligence \& Planning, 22 (6), pp. 663-672. 
Hales, C. (1994), Internal Marketing As an Approach to Human Resource Management: A New Perspective Or A Metaphor Too Far? Human Resource Management Journal, 5(1), pp. 50-71.

Harker, M.J. \& Egan, J. (2006) The Past, Present and Future of Relationship Marketing Journal of Marketing Management (Special Issue on Relationship Marketing), 22, pp. 215242.

Herstein, R. \& Zvilling, M. (2010), The key role of employees in making customers more loyal, Human Resource Management International Digest, 18(4), pp. 14-19.

Heskett, J.L., (2002) Beyond customer loyalty, Managing Service Quality, 12(6), pp.355 - 357.

Heskett, J.L., Sasser, W.E. Jr \& Schlesinger, L.A. (1997), The Service Profit Chain. How Leading Companies Link Profit and Growth to Loyalty, Satisfaction, and Value, New York: Free Press.

Hughes, S. \& Bolton, T. (2002), Work-life balance, London: Spiro.

Hult, T. (2011), Toward a theory of the boundary-spanning marketing organization and insights from 31 organization theories, Journal of the Academy of Marketing Science, 39, pp. $509-536$.

Hunt, S.D. (1997) Competing Through Relationships: Grounding Relationship Marketing in Resource-Advantage Theory, Journal of Marketing Management, 13, pp. 431445.

Ind, N. (2001), Living the brand: How to transform every member of your organization into a brand champion, London: Kogan Page. 
Iocabucci, D. \& Ostrum, A. (1996) Commercial and interpersonal relationships; Using the structure of interpersonal relationships to understand individual-to-individual, individualto-firm, and firm-to-firm relationships in commerce, International Journal of Research in Marketing, 13, pp.53-72.

Judd, V.C. (1987), Differentiate with the 5th P: People, Industrial Marketing Management, 16, November, pp.241-247.

Kalatatis, S.P. \& Miller, H. (1996) A re-examination of the commitment-trust theory, presented at: 12th IMP Conference, University of Karlsruhe.

Kale, S. H. (2007). Internal Marketing: An Antidote for Macau's Labor Shortage. UNLV Gaming Research \& Review Journal, 11(1), pp.1-11.

Kent, R.A. (1986) Faith in the 4P's: An Alternative, Journal of Marketing Management; 2(2), pp.145-154.

Kiechel, W. (1985), " Resurrecting Corporate Loyalty,". Fortune (December 9), 209-11

Labovitz, G. and Rosansky, V. (1997), The Power of Alignment: How Great Companies Stay Centered and Accomplish Extraordinary Things, John Wiley \& Sons, Inc., New York, NY.

Lee, M. (2001), A refusal to define HRD, Human Resource Development International, 4(3), pp. 327-341.

Lehtinen, J. R. (1983), Improving service quality by analyzing the service production process. In (eds) C. Grönroos, \& E. Gummesson, , Service Marketing - Nordic School Perspectives, University of Stockholm, Stockholm 
Lengnick-Hall, M. A., Lengnick-Hall, C. A., Andrade, L. S. \&, Drake, B. (2009) Strategic human resource management: The evolution of the field Human Resource Management Review 19(2), pp. 64-85.

Maynard, T., Gilson, L. \& Mathieu, J. (2012), Empowerment—Fad or Fab? A Multilevel Review of the Past Two Decades of Research, Journal of Management, 38(4), pp. $1231-1281$.

McCarthy, E.J. (1960), Basic Marketing, Homewood: Irwin

McGarry, E.D. (1950) Some Functions of Marketing Reconsidered in (eds) Cox, R. and Alderson, W. Theory of Marketing, Chicago: Irwin

McGoldrick, J., Stewart, J. \& Watson, S. (2002), Understanding HRD: a research based approach, International Journal of Human Resource Development and Management, 2(1), pp. $17-30$.

McGoldrick, J., Stewart, J. \& Watson, S. (2002), Researching HRD, in (eds) McGoldrick, J., Stewart, J. and Watson, S. Understanding Human Resource Development: A research-based Approach, London: Routledge , pp. 1-17.

McKitterick, J.B. (1957) What is the Marketing Management Concept?, in (ed) Bass, F. The Frontiers of Marketing Thought in Action, Chicago: AMA

Meyer, J., \& Allen, N., (1997), Commitment in the work place: theory, research and application. London: Sage Publications.

Mintzberg, H., Ahlstrand, B. \& Lampel, J. (1998), Strategy Safari: A Guided Tour through the Wilds of Strategic Management, New York, NY: The Free Press. 
Moorman, C., Zaltman, G. \& Deshpande, R. (1992), Relationships Between Providers and Users of Market Research: The Dynamics of Trust Within and Between Organisations, Journal of Marketing Research, 29, August pp. 314-328.

Morgan, R., M., \& Hunt, S., D., (1994), The commitment trust theory of relationship Marketing, Journal of Marketing, 58 (3), pp. 20-38.

Morley, M., Gunnigle, P., \& O’Sullivan, M., \& Collings, D. (2006) New directions in the roles and responsibilities of the HRM function, Personnel Review 35(6), pp. 609-617.

Normann, R. (1983), Service Management, New York: Wiley.

O’Malley L. \& Tynan, C. (1999) Concept, Metaphor or Reality?: The Prognosis for Relationships in Consumer Markets, Journal of Marketing Management, 20(10), pp. 571579.

Onyemah, V. , Rouziès, D. \& Panagopoulos, N. (2010), How HRM control affects boundary-spanning employees' behavioural strategies and satisfaction: the moderating impact of cultural performance orientation, The International Journal of Human Resource Management, 21(10), pp. 1951-1975.

Parasuraman, A., Berry, L.L. \& Zeithaml, V.A. (1991), Understanding customer expectations of service, Sloan Management Review, 39, Spring, pp. 39-48

Pfeffer, J. (1998), The Human equation. Boston: Harvard Business School Press

Porter, M. (1985), Competitive advantage. New York: The Free Press

Rafiq, M. \& Ahmed, P. (1993) The scope of internal marketing: Defining the boundary between marketing and human resource management, Journal of Marketing Management, 9(3), pp. 219-232. 
Reichheld, F. F. \& Sasser, W. E. Jr. (1990), Zero Defections: Quality comes to Services, Harvard Business Review, 68 (September), pp.105-111

Renwick, D. (2002), Line manager involvement in HRM: an inside view, Employee Relations, 25(3), pp. 262-280

Salancik, G. (1977), Commitment and control of organizational and belief, Malabar, Florida: Kricger Publishing.

Sambrook, S. (2009), Critical HRD: a concept analysis, Personnel Review, 38(1), pp. $61-73$.

Sanders, K., Dorenbosch, L. \& de Reuver, R., (2008), The impact of individual and shared employee perceptions of HRM on affective commitment: Considering climate strength, Personnel Review, 37(4), pp.412 - 425.

Schneider, B., White, S.S. \& Paul, M. C. (1998), Linking service climate and customer perceptions of service quality: test of a casual model, Journal of Applied Psychology, 83( 2), pp. 150-63.

Seibert, S., Wang, G. \& Courtright, S. (2011), Journal of Applied Psychology, 96(5), pp. 981-1003.

Singh, S., Darwish, K., Costa, A.C. and Anderson, N., (2012), Measuring HRM and organisational performance: concepts, issues, and framework, Management Decision, 50(4), $651-667$

Singh, J., Verbeke, W., and Rhoads, G. K. (1996), Do organizational practices matter in role stress processes? A study of direct and moderating effects for marketing-oriented boundary spanners, Journal of Marketing 60(3), pp. 69-86. 
Siikaniemi, L. (2009), Competence and employment forum, linking HRD and HRM, Journal of European Industrial Training, 33(5), pp. 401-418.

Solnet, D., Kralj, A. and Baum, T. (2014) 360 degrees of pressure: the changing role of the HR professional in the international hospitality industry, Journal of Hospitality and Tourism Research, published online 2 January 2013 DOI: 10.1177/1096348012471380

Smaczny, T. (2001), Is an alignment between business and information technology the appropriate paradigm to manage IT in today's organisations? Management Decision, 39(10), pp. 797-802.

Staw, B. \& Salancik, G., (Eds.) (1977), New Directions in Organisational Behavior Chicago, IL: St Clair Press.

Strong, C. A. and Harris, L.C. (2004) The drivers of customer orientation: an exploration of relational, human resource and procedural tactics Journal of Strategic Marketing Vol. 12, Iss. 3, 2004

Taylor, S., Levy, O., Boyacigillier, N. and Beechier, S. (2008), Employee commitment in MNCs: Impacts of organizational culture, HRM and top management orientations, International Journal of Human Resource Management, 19(4), pp. 501-527.

Thompson, P. (2003), Disconnected Capitalism or why employers cannot keep their side of the bargain, Work, Employment and Society, BSA publications limited, SAGE publications, London Thousand Oaks, New Delhi

Tremblay, M., Cloutier, J., Simard, G. Chenevert, D. and Vandenberghe, C. (2010), The role of HRM practices, procedural justice, organizational support and trust in organizational commitment and in-role and extra-role performance, International Journal of Human Resource Management, 21(3), pp. 405-433. 
Van der Zee, J.T.M. \& De Jong, B. (1999), Alignment is not enough: integrating business and information technology management with the balanced scorecard, Journal of Management Information Systems, 16(2), pp. 137-56.

Varey, R. \& Lewis, B. (1999), A broadened conception of internal marketing, European Journal of Marketing, 33(9/10), pp. 926-944

Vargo, S. L. \& Lusch, R. F. (2004), Evolving to a New Dominant Logic for Marketing. Journal of Marketing, 68, pp. 1-17.

Vargo, S. L. \& Lusch, R. F. (2006), Service-dominant logic: reactions, reflections And refinements, 6 (3), pp. 281-288

Vargo, S.L. and Lusch, R.F. (2008a), Why 'service'?, Journal of the Academy of Marketing Science, 36(1), pp. 25-38.

Vargo, S.L. and Lusch, R.F. (2008b), Service-dominant logic: continuing the evolution, Journal of the Academy of Marketing Science, 36, Spring, pp. 1-10.

Vargo, S.L. (2009), Toward a transcending conceptualization of relationship: a servicedominant logic perspective, Journal of Business \& Industrial Marketing 24(5/6) , pp. 373379.

Vince, R. (2012), Emotion, Politics and Learning: Toward an Organizational Orientation in Human Resource Development, in (eds), Lee, M., Stewart, J. and Woodall, J. New Frontiers in HRD, London: Routledge, pp.130-150. 
Vlaar, P., Van Den Bosch, F. \& Volberda, H. (2007), On the Evolution of Trust, Distrust, and Formal Coordination and Control in Interorganizational Relationships. Toward an Integrative Framework, Group and Organization Management, 32(4), pp. 407-428.

Walton, R. E. (1985), From control to commitment in the work place. Harvard Business review, March/ April, pp. 77-84.

Wang, G., Oh, I., Courtright, S. \& Cobert, A. (2011) Transformational Leadership and Performance Across Criteria and Levels: A Meta-Analytic Review of 25 Years of Research Group and Organization Management, 36(2), 223-270.

Waterschoot, W. \& Van Den Bulte (1992), The 4P's Classification of the Marketing Mix Revisited, Journal of Marketing, 56 (October), pp. 83-93.

Wells, B. and Spinks, N. (1998), Organizational Communication: A Strategic Approach, 5th ed., Dame Publications, Houston, TX.

Whetton, D.A. (1989) What constitutes a theoretical contribution? Academy of Management Review, 14(4), pp. 490-495.

Whitener, E. (2001), Do "high commitment" human resource practices affect employee commitment? A cross-level analysis using hierarchical linear modelling, Journal of Management, 27, pp.515-535.

Wiener, Y. (1982), Commitment in organisations: a normative view. Academy of Management Review, 7 (3), pp. 418-428.

Wood, S. \& Albanese, M. (1995), Can we speak of high commitment management on the shop floor?, Journal of Management Studies, 32 (2), pp. 215-247. 
Yee, R., Yeung, A. and Cheng, T. (2011), The service-profit chain: An empirical analysis in high-contact service industries, International Journal of Production Economics, 130(2), pp.236-245. 